\title{
Porosaamelaisjoiun säveljärjestelmän tutkimuksen piirteitä
}

\section{Duuri-molli-tonaalinen analyysiparadigma}

Tässä artikkelissa esittelen joikumelodioiden sävelten melodisiin sävelfunktioihin ja painoarvoon eli prominenssiin perustuvan analyysimallin, jota sovellan sekä yksittäisten joikujen että joikutoisintojen sävelikköanalyysissa. Tarkoituksenani on kehittää analyysimalli, jonka avulla joikumelodioiden oma logiikka tulee mahdollisimman hyvin esille. Tarve uudenlaisen metodin kehittämiseen on noussut niistä kysymyksistä, jotka ovat heränneet, kun olen yrittänyt soveltaa aiemman tutkimuksen metodeja tutkimusaineistooni ${ }^{1}$.

Saamelaisjoiun musiikkianalyyttisen tutkimuksen aloitti Suomessa Armas Launis (1884-1959) vuonna 1908 ilmestyneellä Lappische Juoigos-Melodien -teoksella, joka on noussut ilmestymisensä jälkeisen sadan vuoden aikana koko suomalaisen joikututkimuksen klassikoksi. Sitä on käytetty pääasiassa uusien tutkimusten esimerkkiaineistona, jolloin nuotinnokset on esitetty sellaisenaan ilman uutta analyysia (ks. Leisiö 1978; Laitinen 1981). Launiksen kokoelman joikumelodioita on käsitelty myös arkistoaineiston tapaan ${ }^{2}$. Tällöin niiden pohjalta on tehty uusia johtopäätöksiä (ks. Laitinen 1981; Kantola 1984; Kádár 1990; Saastamoinen 1994; 1998; Järvinen 1999; Jouste 1998; 2000).

Vaikka Launiksen keräämä laaja joikuaineisto antaa mahdollisuuden monenlaisiin analyyseihin, sen käyttö rajoittuu vain niihin piirteisiin, joita länsimainen nuottikirjoitus sisältää. Tutkimuksen ulkopuolelle jäävät esimerkiksi äänenväri, dynamiikka, hengitystekniikka, melodian, rytmin ja tekstin variointi sekä melodioiden tarkat sävelkorkeudet. Jos tutkija haluaa tehdä analyysia muusta kuin duuri-molli-tonaalista näkökulmasta, aineisto on järjestettävä uudelleen. Teoksen joikujen nuotinnustapaan, aineiston jär-

1 Tässä esitellyt analyysiongelmat nousivat esiin selvittäessäni mm. Inarin porosaamelaisen Jouni Gabrielinpoika Aikion (1875-1956) eli Kaapin Jounin 208 joiun repertuaarin säveljärjestelmää. Alun perin Armas Launiksen (1908) kokoelmassa julkaistujen Kaapin Jounin joikujen analyysi oli osa tätä artikkelia, mutta kokonaisuus kasvoi liian suureksi ja itse analyysi tullaan julkaisemaan myöhemmin.

2 Samaan tapaan on käsitelty myös K. Tirénin teosta Die Lappische Volksmusik (1942) sekä Aikion, Keskemétin ja Kissin teosta Lappische Joiku-Lieder aus Karasjok (1972). 
jestelyyn ja erityisesti joikujen metrin esitystapaan liittyviä ongelmia on käsitelty lukuisissa joikututkimuksissa hieman eri painotuksin, mutta mitään kokonaisesitystä ei ole tästä toistaiseksi julkaistu.

Käsittelen tässä yhteydessä joikua pelkästään musiikillisena ilmiönä ja kiinnitän huomiota vain sävelkorkeuksiin. Joiku, kuten kaikki musiikki, on luonnollisesti paljon sävelkorkeuksia laajempi kulttuurinen kokonaisuus.

Launiksen joiun tutkimiseen soveltamien analyysimenetelmien taustalla oli Launiksen opettajan Ilmari Krohnin (1867-1960) teoreettinen ajattelu, vaikka Launis itse myös kehitti analyysimenetelmäänsä. Krohnilainen kansanmusiikin tutkimuksen musiikkianalyyttinen metodi perustui 1900-luvun alussa ajatukseen universaalista duuri-molli-tonaliteetista, jonka avulla uskottiin voitavan selittää kaikenlaista musiikkia aina sinfonioista luonnonkansojen musiikkeihin. Krohn esittelee sävelopissaan melodia-analyysin lähtökohtia seuraavasti:

\footnotetext{
"Olemme ehdottomasti vakuutetut siitä, että kaikkien aikojen ja kansojen musiikilla on yhteiset sekä tonaaliset että rytmilliset peruslait, jotka johtuvat sävelten luontoperäisestä olemuksesta ja niiden sielullisesta vaikutuksesta ihmisluontoon." [...] " [...] vaikka nämä lait ovat ainoastaan länsimailla ja vasta viime vuosisatoina tulleet teoreettisesti täysin tajutuiksi."
}

(Krohn 1916, 10; 74)

Krohnin ajatus musiikin universaaliudesta on lähtöisin 1800-luvun saksalaisilta taidemusiikin tutkijoilta, erityisesti Hugo Riemannilta (1849-1919). Riemann oli yksi duurimolli-tonaliteetin sävelfunktioiden tärkeimmistä teoretisoijista. Hän yhdisti toisiinsa musiikin universaalisuuden ja toisen 1800-luvun suuren teorian, evolutionismin. Musiikin historian tutkimuksen tehtävänä oli Riemannin mielestä osoittaa miten duurimolli-tonaalinen periaate täsmentyy kansojen kulttuurisen kehitysasteen noustessa (Huttunen 1993, 81).

Samoihin aikoihin krohnilaisen koulukunnan kanssa vaikutti myös muita musiikin tutkimuksen suuntauksia. Saamelaisia joikuja käsiteltäessä kiinnostavia ovat erityisesti ne tutkijat, jotka pohtivat ulkoeurooppalaisten kansojen musiikkien säveljärjestelmiin liittyviä ongelmia. Näitä olivat mm. englantilainen Alexander John Ellis (1814-1890) ja ns. Berliinin koulukunnan Carl Stumpf (1848-1936), Erich von Hornbostel (1877-1935) ja Otto Abraham. (1872-1926) Näiden yhteisenä huomiona oli se, ettei kaiken musiikin perustana voinut olla universaali duuri-molli-tonaliteetti, vaan eri musiikkikulttuurien säveljärjestelmät noudattavat omaa logiikkaansa. Eri kansojen musiikkia keräämällä ja niiden säveljärjestelmiä vertailemalla haluttiin luoda kokonaiskuva ihmiskunnan jakautumisesta erilaisiin musiikkikulttuurisiin alueisiin sekä selvittää niiden keskinäisiä sukulaisuussuhteita. Tämän ajatuksen pohjalta syntyi vertaileva musiikkitiede (Pekkilä 1984, 143-147).

Krohn (1916,9-10) tunsi vertailevan musiikkitieteen edustajien ajatukset, mutta piti kiinni universaalista tonaliteetin käsityksestä, koska se oli hänen mukaansa ainoa keino 
saavuttaa yhtenäinen vertailun pohja kaikelle musiikille. Hänen mielestään Euroopassa keskiajan loppupuolella kehittynyt soinnullisuus perustui aiempaan yksiääniseen musiikkiin, jonka lait olivat olemassa myös myöhemmässä soinnullisessa musiikissa, vaikkakin teoreettisesti unohdettuina. Oman aikansa analyysimenetelmien soveltaminen arkaaisempaan musiikkiin oli siis oikeutettua. Varhaisempia tonaliteetin muotoja pystyttiin selvittämään erityisesti yksiäänisen kansanmusiikin tutkimuksen avulla.

Musiikkianalyyttisesti luonnonkansojen tai ulkoeurooppalaisten kansojen musiikkien tutkimuksessa yhtenä suurimmista ongelmista oli perussävelen määritteleminen (vrt. Nettl 1956, 46-50), sillä vain tuntemalla perussävel katsottiin voitavan havaita säveljärjestelmälle ominaiset sävelten väliset suhteet. Se, että vertailevan musiikkitieteen edustajat näkivät perussävelen puuttumisen tai määrittelemättömyyden todisteena erilaisista tonaliteeteista, ei vakuuttanut Krohnia. Hänen mielestään perussävel ei ole ainoa tonaliteetin edustaja vaan kaikilla diatonisen asteikon kantasävelillä on vaikutuksensa sävelmän laatuun ja koossapitoon.

\footnotetext{
"On vaan tutkittava melodisten tukikohtien nojalla, mille säveljärjestön sävelille tonaalinen painopiste kulloinkin siirtyy. Siten voidaan määritellä sävelmän perussävel sekä ne kantasävelet, jotka perussävelen ohella tai sijalla esiintyvät tonaalisesti painavimpina, aikaansaaden sen erikoisvärityksen, joka sävelmän soidessa välittömästi tuntuu." (Krohn 1916, 73)
}

Krohnin tonaalisuuskäsitteeseen kuuluvat hänen mukaansa kaikki musiikilliset ilmiöt, niin uuden ajan soinnullisuus, kuin sitä historiallisesti edeltävä kirkkosävellajimodaliikka tai Aasian musiikkikulttuurien ja luonnonkansojen pentatoniikkakin. Jälkimmäisen ryhmän kohdalla on mielenkiintoinen Krohnin ajatus tonaliteetin ratkaisemattomuudesta. Tällaisissa tapauksissa melodiassa käytetyt sävelet eivät anna mahdollisuutta määritellä perussävelen ja muiden sävelten suhteita eivätkä näin ollen myöskään melodian tonaalista ilmettä.

\footnotetext{
”Sellaiset sävelmät ovat ikään kuin „kaksi- (tahi kolmi-) naamaisia”. Sen mukaan, mikä sävel käsitetään perussäveleksi, vaihtuu toistenkin sävelten tonaalinen merkitys ja saa koko sävelmä eri luonteen. Tähän seikkaan juuri perustuukin mainittu väite tonaalisuuskäsitteen puuttumisesta tai perinpohjaisesta erilaisuudesta. Mutta sellainen johtopäätös on ennenaikainen. Sillä useampien eri perussävelien mahdollisuudesta johtuva "moninaamaisuus” ei tee tyhjäksi sitä tosiasiaa, että kuitenkin j o n k u n sävelen tulee olla sävelmän tonaalisuutta tukeva perussävel. Eikä ole edes yhdentekevää, mikä vaihtoehtoisista mahdollisuuksista oletetaan todelliseksi; sillä sen mukaisesti vaihtuu aina myös sävelmän luonne.” (Krohn 1916, 73-74.)
}

Krohnin käsitys tonaalisen kehityksen luonteesta ei ole yksioikoinen. Kehitys ei sulje pois aiempia saavutuksia, vaan myös myöhempien taidemusiikin säveltäjien teoksista löytyy pentatonisia tai kirkkosävellajeihin perustuvia sävelkulkuja samoin kuin melodioita joissa ilmenee ratkaisemattoman tonaalisuuden ilmiö. Krohnin tonaalisuuskäsite sulkee siis kaiken musiikin sisäänsä. Pentatonisuus, johon saamelaiset joiut Krohnin ja Launiksen mukaan perustuvat, saa myös oman käsittelynsä osana universaalia tonaliteettia. 


\begin{abstract}
"Varmasti voidaan myös päättää, että pentatoniikka edustaa ihmiskunnan varhaisimpien sivistyskausien saavutusta musiikkityylin alalla. Pentatonisesta melodiikasta on sitten diatoninen luonnollisesti sukeutunut, arvattavasti alkeellisten resitatiivisten ainesten avulla. Tämän kautta osottautuu myös oikeutetuksi se järjestelmä, jota noudattaen olemme tähän asti oppijaksossa sävel säveleltä kehitelleet käytettäväämme sävelainesta." (Krohn 1916, 268)
\end{abstract}

Krohn (1916, 265-283) selittää pentatoniikan syntyneen duurin perus-, terä- ja huippusävelen (c-d-g) sekä mollin perus-, lepo- ja huippusävelen (a-d-e) yhdessä muodostamasta asteikosta. Siirrettäessä sävelet samaan oktaavialaan saadaan duuripentatoninen asteikko $c-d-e-g-a$ ja mollipentatoninen asteikko $a-c-d-e-g$. Näiden kahden ohella pentatonisia asteikkoja on useita eri lajeja riippuen siitä, mitä säveliä tarvitaan täydennykseksi, jotta asteikko muuttuisi diatoniseksi. Krohn mainitsee Launiksen kehittämän järjestelmän, jonka asteikoista mielenkiintoisimmiksi osoittautuvat sekä taidemusiikissa että luonnonkansojen, esimerkiksi saamelaisten sävelmissä esiintyvät seuraavat muodot: $g-a-c-d-e, g-h-c-d-e, g-a-h-d-e$ ja $g-a-h-c-e$.

Launis (1908, xxxi) toteaa Lappische Juoigos-Melodien -teoksen alkupuheessa kiintoisaa olevan sen, että joikujen melodiat ovat enimmäkseen pentatonisia tai pentatonisten asteikkojen vajaamuotoja, eli niiden säveliköt koostuvat vähemmästä kuin viidestä sävelestä. Launis käsitteli joikujen pentatonisuutta tarkemmin vuonna 1909 julkaistussa artikkelissa Die Pentatonik in den Melodien der Lappen. Joikukokoelmassaan hän toteuttaa kuitenkin riemannilais-krohnilaista duuri-molli-tonaliteetin logiikkaa, vaikka selvästikin haki parasta mahdollista tonaalisen teorian sovellutusta joikujen oman logiikan löytämiseksi. Tästä kertoo mm. se, että hän vähensi melodian osuutta suhteessa säerakenteisiin järjestelleessään joikukokoelmaansa. Aineiston tyypittely määräytyy seuraavassa järjestyksessä: 1) säkeitten jakautuminen ja iskuluku, 2) ensimmäisen säeparin motiivit, 3) ensimmäisen säkeen korkein iskullinen sävel ja 4) sävellaji ja melodinen ulottuvuus (Launis 1908; Väisänen 1990, 211).

Duuri-molli-tonaalisen kansanmusiikin paradigman tutkimuksen positiivisena piirteenä voi nähdä sen, että sen avulla päästiin ensimmäisen kerran käsittelemään ja järjestelemään mittavia länsimaisesta taidemusiikista poikkeavia sävelmäaineistoja. Yhtenäisteorian pohjalta kehitettiin tonallisuuden rajoissa sovellutuksia kansallisiin erityistapauksiin kuten esimerkiksi suomalaisiin kansanlauluihin tai saamelaiseen joikuun. Siirryttäessä etäämmäs eurooppalaisesta taidemusiikkiperinteestä aineistojen pakottaminen tonaalisiin muotteihin tuotti ongelmia. Vieraat musiikit jäivät tutkimuksista huolimatta vieraiksi. Teoreettisesti ne selitettiin primitiivisiksi tonaalisuuden esiasteiksi eikä niistä odotettukaan löytyvän kuin heikkoja aavistuksia tonaalisuudesta (Huttunen 1993, 76).

\title{
Pentatonisen analyysin paradigma
}

Launiksen jälkeen joikumelodioiden musiikkianalyysia tehtiin Suomessa hyvin vä- 
hän ennen 1970-lukua ${ }^{3}$, jolloin uusi amerikkalaisen etnomusikologian suuntaus alkoi vaikuttaa tutkimuksessa. Seuraava joikututkimuksen musiikkianalyyttinen paradigma on korostanut joikumelodioiden duuri-molli-tonaliikasta poikkeavaa pentatonista luonnetta. Tutkijoiden analyysimalli on pääosin ollut verrattavissa etnomusikologian ulkoeurooppalaisten musiikkikulttuurien analyysimalliin (ks. esim. Nettl 1956; 1964; Sachs 1962; Hood 1982) tai itäeurooppalaisen kansanmusiikintutkimuksen malliin (ks. esim. Brăiloiu 1984, 239-289). Voidaan kuitenkin väittää, että suomalaisen kansanmusiikin tutkimuksen voimakkaan perinteen ja joikututkimuksessa erityisesti Launiksen työn kautta ovat myöhemmätkin suomalaiset joikututkijat ainakin jollain tavoin olleet sidoksissa krohnilaiseen ajatteluun.

Pohjoissaamelaisen joiun pentatonisen tulkinnan periaatteen ja sen eron tonaaliseen musiikin nähden käy ilmi seuraavasta Heikki Laitisen (1981, 184-185) kuvauksesta, jossa on kuitenkin mukana mm. Launiksen ajatus pentatonisisten asteikkojen vajaamudoista:

\begin{abstract}
"Entä Pentatonisuus? Tämä sana pyrkii kuvaamaan joikujen musiikillista ajattelua. Se poikkeaa nimittäin täydellisesti esimerkiksi suomalaisesta sävellajiajatteluun (duuri-molli) perustuvasta musiikkitajunnasta. Pentatonisuus [...] tarkoittaa [...] puolisävelaskeleetonta pentatoniikkaa; asteikko koostuu viidestä sävelestä [...], joiden välit ovat joko suuria sekunteja tai pieniä terssejä. [...] Joiun melodiikalle on ominaista avosävyisempien, luonnollisempien intervallien (kvartti, kvintti, oktaavi) ja duurikolmisointukulkujen keskeinen asema, suurtenkin intervallien käyttö sekä sävelkulun ylös-alas hyppelehtivä, edestakainen liike. Joiun pentatoniikkaa voisi kutsua nimellä (pohjois)saamelainen duuripentatoniikka. Jokaisessa joiussa ei tietenkään tarvitse kaikkien asteikon sävelien olla edustettuina. Joikujen kokonaisuus osoittaa kuitenkin, että oma pentatoninen ajatteulutapa muodostaa saamelaisen musiikillisen ajattelun perustan. (Laitinen 1981, 184.)
\end{abstract}

Suomalaisen joikututkimuksen pentatoniseen ajatteluun liittyy olennaisesti myös ajatus melodioissa vallitsevasta sävelhierarkiattomuudesta:

\begin{abstract}
"Puolisävelaskeleettomassa pentatoniikassa sävelet eivät ole tällä tavalla (funktionaalisen harmonian tapaan) toisilleen alistettuja. Siksi vähemmistä sävelistä syntyy spontaanisti paljon loputtomammin eriluonteisia yhdistelmiä, eri sävelmiä. Ne kaikki ovat kuin saman asian eri puolia, näytteitä tai katkelmia aluttomasta ja loputtomasta, erään kansan monituhatvuotisen kulttuurihistorian muovaamassa uomassa soljuvasta sävelten virrasta. Puolisävelaskelten ja muiden kiihkeästi riitasointisten intervallien puuttuminen tekee joikusävelmistä musiikilliselta sävyltään avoimia ja rauhallisia. Niistä puuttuu ristiriita ja jännite, joiden varaan sävellajiajattelu pyrkii melodiat rakentamaan." (Laitinen 1981, 185.)
\end{abstract}

Sama ajatus joikujen pentatonisuudesta ja sävelhierarkiattomuudesta esiintyy myös Tuula Kantolan $(1984,38)$ Talvadas-tutkimuksessa, jossa hän toteaa Laitiseen viitaten, että puolisävelaskeleettomassa pentatoniikassa sävelet ovat samanarvoisia, eivät

3 Väisänen käsitteli joikua artikkeleissaan Ukko-Pekan joiku ja Pari kolttain sävelmää (Väisänen 1990). Eliel Lagercrantzin seitsenosaisesta Lappische Volksdichtung -teoksesta osat IV ja VI sisältävät musiikkianalyysia (Lagercrantz 1957-1966). Sekä Väisäsen että Lagercrantzin näkemyksensä olivat kuitenkin täysin tonaalisia. 
toisilleen alistettuja kuten duuri-molliasteikossa. Joikujen pentatonisen ja sävelhierarkiattoman tulkinnan vahvaa asemaa kuvaa se, että vuonna 1999 ilmestyneessä väitöskirjassaan Minna Riikka Järvinen toteaa jälleen kerran että:

\begin{abstract}
"Pohjoissaamen itämurteiden alueen joiut perustuvat pääosin puolisävelaskeleettomalle pentatoniikalle. Tämä ei ole kuitenkaan ehdotonta, vaan joiuissa on runsaasti myös puolisävelaskelia sisältäviä pentatonisia asteikkoja ja myös laajempia asteikkorakenteita. Melodian kaarroksessa asteikon sävelet ovat tasa-arvoisia, eikä niiden välillä ole tonaalisia jännitteitä duuri- ja molliasteikkojen tapaan". (Järvinen 1999, 98-99.)
\end{abstract}

Mielenkiintoinen on kuitenkin Järvisen toteamus runsaasti esiintyvistä puolisävelaskelia sisältävistä pentatonisista asteikoista. Laitinenkin $(1981,187)$ huomauttaa, että kolmasosassa tallennetuista sävelmistä pentatonisuus ei ole aivan ehdotonta, vaikka nämä eivät melodianmuodostukseltaan poikkea puhtaasti pentatonisista.

Pentatonisen analyysiparadigman ansio on se, että se tunnustaa omaperäisen saamelaisen säveljärjestelmän olemassaolon ja arvon. Tähänastiset tutkimukset ovat kuitenkin pääosin joikumelodioita ja niiden sävelikkö- ja intervallirakenteita kuvailevia, eikä niissä juurikaan lähestytä kysymystä siitä, miten joikujen säveljärjestelmä toimii. Lisäksi pentatonisessa analyysissä ovat olleet käytössä pitkälti tonaaliseen musiikkiin kehitetyt analyyttiset metodit ja terminologia ${ }^{4}$. Joikututkimuksen pentatonisen paradigman oletukset, kuten joikumelodioiden sävelhierarkiattomuus, diatonisten ja pentatonisten sävelikköjen vajaamuodot herättävät kuitenkin kysymyksiä siitä, ovatko käytetyt musiikkianalyyttiset metodit sittenkään olleet riittäviä ja ovatko analyysit kohdistuneet joiun olennaisimpiin piirteisiin.

Pentatonisissa tutkimuksissa yleisesti hyväksyttyjä oletuksia ei ole itse tutkimuksissa kuitenkaan sen kummemmin perusteltu teoreettisesti. Implisiittisesti käsitys joikujen sävelhierarkiattomuudesta lähtee erityisesti duuri-molli-tonaliteettin kuuluvasta ajatuksesta, että jännitettä luovat puolisävelaskeleet vetävät toisiaan puoleensa enemmän kuin kokosävelaskeleen päässä toisistaan olevat sävelet. Jos puolisävelaskelia ei löydy melodiasta, niin tämän logiikan mukaan sävelten välillä ei ole havaittavissa vetovoimaa ja ilman tätä ei mikään pentatonisen sävelikön sävelistä saada toisiin säveliin nähden hallitsevampaa osuutta ja muodostua vaikkapa perussäveleksi. Tosin perussävelen tuntu voidaan saavuttaa hetkellisesti jos jotain sävelastetta korostetaan melodiassa tarpeeksi voimakkaasti.

Joikumelodioiden analysoiminen hierarkiattomiksi tuntuu oudolta, varsinkin kun etnomusikologian analyysimetodeissa on jo sadan vuoden ajan korostettu juuri länsimaisesta tonaliteetista poikkeavien säveljärjestelmien sävelhierarkioiden tutkimista

4 Tällainen on esimerkiksi itävaltalaisen Oswald Kollerin melodioiden luokittelemiseen kehittämä sävelten numeroimisjärjestelmä, joka kuitenkin kuvaa pitkälti sävelten tonaalisia suhteita. 
(ks. esim. Herzog 1928, 191-192; Hornbostel 1928, 36; Sachs 1962; Nettl 1964; 146148; Hood 1982, 326). Ajatus, että joiuista ei löydy duuri-molli-tonaalisuuteen kuuluvia jännitteitä ei suinkaan merkitse, etteikö joikumelodioissa voisi olla omaan säveljärjestelmäänsä kuuluvaa jännitettä5.

Ajatuksen joikumelodioiden vajaamuotoisista säveliköistä voi sen sijaan johtaa useisiin lähteisiin, vaikkei niitäkään joikututkimuksissa erikseen mainita. Berliinin koulukunnan tutkijat Otto Abraham ja Eric von Hornbostel määrittelivät vuonna 1903 kolme sävelikköanalyysin käsitettä. Nämä ovat melodioissa ilmenevä käyttöasteikko (Gebrauchsleitern), laajemmissa melodioiden kokoelmassa ilmenevä materiaaliasteikko (Materialleitern) sekä soittimia käyttävässä musiikkikulttuurissa ilmenevä instrumentaaliasteikko (Instrumentalleitern) (Pekkilä 1984, 145). Periaatteessa samanlaisen jaon tekee myös amerikkalainen etnomusikologi Mantle Hood (1982, 324). Hänen mukaansa sävelikköanalyyissa pitää ensin määritellä kaikki tutkittavassa säveljärjestelmässä olevat sävelkorkeudet ja sen jälkeen analysoitava tutkittavassa melodiassa esiintyvät sävelet.

Joikumelodioiden analysoimisessa vajaiksi muodoiksi on siis kyse käyttöasteikon ja materiaaliasteikon välisestä suhteesta. Mutta millä perusteella joikumelodioista puuttuu joitain säveliä ja mitä nämä puuttuvat sävelet ovat (ks. myös Leisiö 2001, 100)? Ovatko joiut jollain tavoin epätäydellisiä sellaisenaan? Analysoidaanko vastaavasti Sibeliuksen musiikista säveliä, joita hän ei säveltänyt?

Kaiken kaikkiaan useissa tutkimuksissa esitelty joikujen säveljärjestelmä vaikuttaa aivan liian monimutkaiselta ja jopa kaoottiselta ollakseen kehittynyt täysin muistinvaraisessa kulttuurissa, ilman soittimia, ilman eriytynyttä muusikkojen yhteiskuntaluokkaa ja jossa lähes kaikki yhteisön jäsenet osallistuvat musiikin tekemiseen. Muistinvaraisessa musiikkikulttuurissa on tärkeää, että kuulijan täytyy voida oppia ja sisäistää joiut yhdellä tai kahdella kuuntelukerralla. Tämän jälkeen hänen on jo kyettävä tekemään niistä oman versionsa. Joikujen melodisten ja metristen rakenteiden on siis oltava ennen kaikkea loogisia kulttuurinsisäisestä näkökulmasta ${ }^{6}$.

Joikaajien kanssa käydyissä keskusteluissa tulee ilmi se seikka, että on olemassa joiulle tyypillinen tapa muodostaa melodioita ja jos tätä ei noudateta, ei kyseinen musiikki ole enää joikua ${ }^{7}$. Miksi nämä säännöt eivät ole tulleet esiin lukuisissa musiikkianalyyttisissä tutkimuksissa? Usein vedotaan siihen, että joiku on musiikkina niin kulttuurisidonnaista, ettei sitä pysty ymmärtämään, ellei ole kasvanut perinteiseen saamelaiseen yhteisöön

\footnotetext{
5 Myös Riitta Rautio (1994) on kritisoinut pentatonisuuteen liitetyn sävelhierarkiattomuuden ideaa suppeassa viiden Tuula Kantolan nuotintaman joiun analyysissa.

6 Vrt. Saastamoinen $(1994,6)$. Hän tosin käyttää loogisen tilalla sanaa yksinkertainen, mutta eihän loogisen ei tarvitse välttämättä olla yksinkertaista.

7 Ulla Pirttijärven luento 1998; Juhani Maggan haastattelu 2001; Jouni Maggan haastattelu 2001. Matti Morottajan mukaan joikumelodiat sisältävät paljon pieniä vivahteita, jotka eivät välttämättä välity joikua tuntemattomille kuulijoille (Kantola 1984, 46).
} 
(vrt. Laitinen 1981, 182-183). Joiun kommunikatiivisen ja kuvauksellisuus-periaatteen kannalta tämä on toki ensisijaisen tärkeää, mutta on oltava myös musiikkianalyysissa esiin tulevia piirteitä, jotka yhdistävät tyylillisesti esimerkiksi yhden joikaajan repertuaarin joiut tai samaa kohdetta kuvaavat joiut toisiinsa.

\section{Joiun säveljärjestelmän additionaalinen luonne}

Eri musiikkikulttuurien säveljärjestelmät voidaan jakaa karkeasti kahteen ryhmään, divisiivisiin ja additiivisiin niiden syntymekanismin perusteella ${ }^{8}$. Divisiivisten säveljärjestelmien ryhmä perustuu perusintervallin, esimerkiksi oktaavin, kvintin tai kvartin jakamiseen pienempiin osiin. Tämä piirre on seurausta ainakin jonkin asteisesta musiikkikulttuurin säveljärjestelmän teoretisoinnista ja sen apuna käytetyistä soittimista. Divisiivisisiä säveljärjestelmiä ovat esimerkiksi länsimainen duuri-mollitonaliteetti, persialais-arabialais-turkkilainen maqam-järjestelmä, antiikin kreikkalaisten ja keskiajan moodit ja kiinalainen ja japanilainen pentatoniikka. Tunnusomaiseksi nousevat teoreettiset sävelkorkeudet, joiden avulla erotetaan sävelasteet ja niille määritellyt affektit toisistaan.

Additiivisten säveljärjestelmien ryhmässä suppeaan sävelten perusjoukkoon lisätään uusia säveliä ja näin laajennetaan melodioita ja samalla myös niissä esiintyviä sävelikkörakenteita ${ }^{9}$. Sävelkorkeudet ovat additiivisessa säveljärjestelmissä divisiiviseen verrattuna paljon suhteellisempia, esittäjästä riippuvaisia. Saamelainen musiikkikulttuuri, joka perustuu ensisijaisesti ihmisäänen estetiikkaan ${ }^{10}$, kuuluu additiiviseen ryhmään. Ei ole todisteita saamelaisten käyttäneen muuta soitinta kuin rumpua ${ }^{11}$. Joikumelodiat eivät ole syntyneet minkään teoreettisen mallin pohjalta eikä niissä ole temperoitua, tasaisiin intervalleihin perustuvaa asteikkoa. Intervallit voivat olla suppeita tai laajoja ilman että melodiassa olisi mitään aukkoja tai vajavaisuuksia (vrt. Hood 1982, 325).

Joikujen sävelikkö- ja melodia-analyysissa tarkkoja sävelkorkeus- tai intervallisuhteita tärkeämmäksi melodiaa järjestäväksi tekijäksi nouseekin melodian liikkeen

\footnotetext{
${ }^{8}$ Termien pohjana on Leisiön $(1988,9)$ ajatus siitä, miten teoreettisesti voidaan ajatella sävelikköjen syntyneen. Useimmiten nämä termit liitetään Sachsin (1962) ajatuksiin erilaisten metristen rakenteiden olemuksesta.

${ }^{9}$ Esimerkiksi Bruno Nettlin $(1956,49)$ mukaan on todennäköistä, että melodiat kehittyivät kaksisävelisistä kolmisävelisiksi jne.

${ }^{10}$ Launis (1986) huomauttaa, että saamelaisten äänenmuodostus on ollut säilyttävä tekijä joikumelodioiden säveljärjestelmässä. Ajatuksen voi kääntää myös siten, että äänenmuodostus on todiste säveljärjestelmän säilyvyydestä.

${ }^{11}$ Ruotsin Lapissa on tosin tunnettu saamelaisten käytettäneen fadno-nimistä ruoko-oboeta (Lüderwaldt $1980,450)$
} 
suunta, sävelten esiintymistiheys ja kokonaiskesto. Joikaaja voi mieltää melodiahypyn samaksi, vaikka sen laajuus muuttuisi esityksen aikana. Divisiivisen säveljärjestelmän mukaisessa analyysissa sävelkorkeutta ei voi muuttaa ilman, että sen funktiota muutettaisiin (vrt. Pekkilä 1984, 159).

1900-luvun alun vertailevan musiikkitieteen edustajat lähestyivät samaa ongelmaa käyttämällä käsitteitä soinnullinen ja ei-soinnullinen musiikki. Tosin he tekivät eron ensisijaisesti länsimaisen musiikin ja ei-länsimaisen musiikin välillä. Kuitenkin seuraava Herzogin vuonna 1928 esittämä ajatus kuvaa hyvin myös divisiivisen ja additiivisen säveljärjestelmän eroavaisuutta:

\footnotetext{
"Primitiivisessä musiikissa melodinen funktio ei ole sidottu mihinkään määättyyn intervalliin vaan se ilmaistaan tietyn alan sisällä. Intervalli täten vaihtelee sen emotionaalisten ja musiikillisten puitteiden mukaan, jotka voivat vaihdella kun melodista säettä toistetaan jatkuvasti, kun sama yksilö toistaa laulun eri tilanteissa tai kun eri laulajat toistavat saman laulun. [...] Tätä variointia rajoittaa kuitenkin se, että kaikkien variaatioiden täytyy ilmaista yhtä ja samaa funktiota. Niinpä kun olemme tekemisissä primitiivisten melodioiden kanssa, voimme tutkimuksessa pelkästään luottaa varsinaisten intervallien melodisiin funktioihin emmekä subjektiivisesti kuultaviin tai edes objektiivisesti mitattaviin intervalleihin.” (Pekkilä 1984, 159.)
}

Samankaltaisen huomion teki myös Curt $\operatorname{Sachs}^{12}(1962,22)$, jonka mukaan musiikkikulttuureissa sävelkorkeuksien ja kestojen pysyvyys liittyy musiikista olemassa olevaan kirjalliseen abstraktioon. Primitiivisissä musiikkikulttuureissa, joista abstraktio puuttuu, ei siis voida täysin luottaa melodian yksittäisten sävelten pysyvyyteen suhteessa säveljärjestelmään.

\section{Joikumelodioiden funktioanalyysi ja prominenssisävelet}

Sävelikkö tai asteikko on tutkijan luoma abstraktio melodiassa esiintyvistä sävelistä. Hornbostelia (Pekkilä 1984, 154) mukaillen sävelikkö on kuvaus vain melodian sisältämien sävelten suhteellisista korkeuksista ottamatta huomioon niiden melodisia funktioita. Säveljärjestelmä ${ }^{13}$ sen sijaan kertoo sävelten melodiset funktiot. Sävelten suhteellinen korkeus ja intervallien koko ovat seurausta näistä funktioista.

Koska joikujen omaan logiikkaan perustuvaa säveljärjestelmää ei ole teoretisoitu tutkimuksessa, vaan pääasiassa on sovellettu jonkin muun musiikin pohjalta kehitettyä säveljärjestelmän mallia - kuten duuri-molli-tonaaliteettia tai pentatoniikkaa -ana-

\footnotetext{
${ }^{12}$ Sachsia ja muita vertailevan musiikkitieteen edustajia on kritisoitu mm. liian universaaleista teorioista. Heidän ansionsa on kuitenkin se, että juuri he tekivät selvän eron duuri-molli-tonaalisen ajattelun ja muun musiikin logiikan välille.

${ }^{13}$ Hornbostel käyttää säveljärjestelmän tilalla moodin käsitettä (Pekkilä 1984, 154).
} 
lyyseissa ei voida lähteä oletuksesta, että joikujen säveljärjestelmä olisi tuttu muille kuin joikukulttuurissa eläville.

Sävelikköanalyyissa on ongelmana se, että pelkät säveliköt eivät kerro esimerkiksi melodian mahdollisista liikkeistä, liikkeiden suunnista, säveleiden vuorovaikutussuhteista tai muista melodiaan liittyvistä periaatteista, joita noudattamalla melodia saa sille ominaisen luonteensa. Joikujen sävelikköanalyysissä täytyy siis huomioida sävelten hierarkkinen järjestelmä.

Sachsin (1962, 64-65) mukaan primitiivisen musiikin sisältämät sävelet eivät kuitenkaan ole tasavertaisia, vaan osasta muodostuu ydinsävelikkö ja osa muodostaa edelliseen lisättyjen sävelten joukon. Hän määrittelee melodiassa ilmenevän ydinsävelikön kunkin sävelasteen kokonaiskeston ja sävelikön intervallirakenteen perusteella. Sävelasteiden kokonaiskestot melodiassa kuvaavat hyvin niiden merkitystä melodiassa. Sen sijaan intervallirakenteiden käyttäminen ensisijaisesti primitiivisen musiikin sävelikköjen määrittelyn pohjana on ristiriidassa edellä esiteltyihin Herzogin ja Sachsin ajatuksiin primitiivisessä musiikissa esiintyvien sävelkorkeuksien suhteellisuudesta.

Seuraavassa joikumelodioiden analyysimallissa käytän käsitteitä sävelfunktio ja prominenssisävel määritelläkseni joikumelodian sävelten välistä hierarkiaa. Sävelten funktioanalyysissa selvitetään melodian jokaisen sävelen kohdalta kaikki mahdolliset sävelten väliset liikkeet. Yksi ensimmäisiä huomioita analysoimissani joiuissa olikin se, että usein intervalliliike rajoittui vain tiettyjen sävelten välille. Duuri-molli-tonaalisessa ja pentatonisessa analyysimallissa oletuksena on se, että kaikki sävelet voivat olla suhteessa toisiinsa.

Sävelten liikettä kuvaavat sävelfunktiot voidaan jakaa kahteen ryhmään. Ensimmäisenä ryhmänä ovat perusfunktiot, joiden tunnusomaisena piirteenä on se, että kullekin sävelelle voidaan tulla ja säveleltä voidaan edetä vain yhteen suuntaan, ylös tai alas. Säveltoistoa ei huomioida, koska siinä on kyse tekstin rytmityksestä. Perusfunktioita on neljää eri tyyppiä:

1) AHS - alahyppysävel, jolle tullaan ylhäältä ja jolta lähdetään ylöspäin (esim. $\left.\mathrm{h}^{1}-\mathbf{a}^{1}-\mathrm{h}^{1}\right)$.

2) YHS - ylähyppysävel, jolle tullaan alhaalta ja jolta lähdetään alaspäin (esim. $\mathrm{g}^{\mathbf{1}}-\mathbf{a}^{\mathbf{1}}-\mathrm{g}^{\mathbf{1}}$ ).

3) AVS - alavälittäjäsävel, jolle tullaan ylhäältä ja jolta lähdetään alaspäin (esim. $\left.\mathrm{h}^{1}-\mathbf{a}^{1}-\mathrm{g}^{1}\right)$.

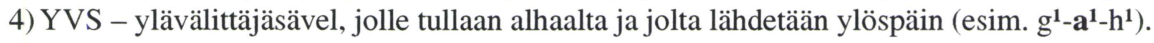

Toisena ryhmänä ovat yhdistetyt funktiot, joille ominainen piirre on se, että samalla sävelasteella yhdistyy vähintään kaksi melodian perusliikettä. Tämä tapahtuu yksiäänisessä laulussa luonnollisesti melodian eri vaiheissa. Yhdistettyjä funktioita on viittä eri tyyppiä:

1) JS1 - jakajasävel 1 (YHS + YVS), jolle tullaan alhaalta ja jolta lähdetään sekä ylösettä alaspäin. Melodiassa on esimerkiksi sekä liike $\mathrm{g}^{1}-\mathbf{a}^{\mathbf{1}}-\mathrm{g}^{\mathbf{1}}$ että $\mathrm{g}^{1}-\mathbf{a}^{1}-\mathrm{h}^{\mathbf{1}}$.

2) JS2 - jakajasävel 2 (AHS + AVS), jolle tullaan ylhäältä ja jolta lähdetään sekä ylösettä alaspäin. Melodiassa on esimerkiksi sekä liike $h^{1}-\mathbf{a}^{1}-h^{1}$ että $h^{1}-\mathbf{a}^{1}-g^{1}$. 

3) JS3 - jakajasävel 3 (AHS + YVS), jolle tullaan sekä alhaalta että ylhäältä ja jolta lähdetään ylöspäin. Melodiassa on esimerkiksi sekä liike $\mathrm{h}^{1}-\mathbf{a}^{1}-\mathrm{h}^{1}$ että $\mathrm{g}^{1}-\mathbf{a}^{1}-\mathrm{h}^{1}$.
4) JS4 - jakajasävel 4 (YHS + AVS), jolle tullaan sekä alhaalta että ylhäältä ja jolta lähdetään alaspäin. Melodiassa on esimerkiksi sekä liike $\mathrm{g}^{1}-\mathbf{a}^{1}-\mathrm{g}^{1}$ että $\mathrm{h}^{1}-\mathbf{a}^{1}-\mathrm{g}^{1}$.
5) JS5 - jakajasävel 5 (AVS + YHS + YVS + AHS). Tällä sävelellä ovat kaikki edelliset melodian funktiot mahdollisia.

Toinen tapa määritellä sävelten välistä hierarkiaa on laskea melodiassa esiintyvien sävelten melodinen painoarvo eli prominenssi, joka kertoo kuinka sävel on määrällisesti edustettuna melodiassa.

Prominenssiarvo saadaan laskemalla ensin sävelikön jokaisen erillisen sävelasteen kokonaiskesto melodiassa. Seuraavaksi lasketaan jokaiselle sävelasteelle liikekerroin. Tämä saadaan laskemalla sävelasteeseen liittyvien intervalliliikkeiden määrä. Koska joikuesitys perustuu melodian kertaamiseen, lasketaan kaikkien sävelten, myös melodian ensimmäisen ja viimeisen sävelen kohdalta sekä säveleen tulo että lähtö. Sävelen esiintyessä kerran melodiassa sen liikekertoimeksi tulee siis luku 2. Jos sävel esiintyy kahdesti tulee kertoimeksi luku $4^{14}$. Lopuksi sävelasteiden kestot kerrotaan liikekertoimella ja kaikkien sävelasteiden kerrottujen arvojen summasta lasketaan kunkin sävelasteen prosenttiosuudet.

Prominenssiarvo ottaa siis huomioon sekä sävelasteeseen liittyvän melodisen liikkeen eli sävelen esiintymistiheyden että sävelten kokonaiskeston. Suurimman arvon saa sävelaste, jolla on eniten kumpaakin. Näin voidaan melodioista muodostaa analyysin tulkintojen tueksi sekä prominenssisäveliköitä, joihin on otettu mukaan vahvimman prominenssiarvon sävelet että melodiasäveliköitä, joissa on huomioitu kaikki melodiassa esiintyvät sävelet. Ne melodiasävelikön sävelet, jotka eivät kuulu prominenssisävelikköön, eivät esiinny niin vahvasti melodiassa ja ovat luonteeltaan marginaalisia (alle 10\%).

Sävelfunktioiden ja prominenssiarvojen avulla analyyttiset tulkinnat saadaan perustumaan melodiassa vahvasti ilmeneviin piirteisiin. Näin määräytyvät melodian keskeiset sävelet ja joikumelodiaan kuuluva hierarkia ja logiikka aukeaa. Samalla metodilla voi myös välttyä tekemästä tonaaliseen tai pentatoniseen analyysiin kuuluvia esioletuksia säveljärjestelmän sääntöjen määrittelyssä. Jos melodioissa on esimerkiksi duuri-molli-tonaalisia piirteitä, ne tulevat kyllä esiin tässäkin analyysimallissa. Olennaista on se, että joikujen säveljärjestelmän suhde muihin musiikkeihin tulkitaan analyysin jälkeen, ei sitä ennen.

\footnotetext{
${ }^{14}$ Koska kaikki luvut ovat parillisia, on luonnollisesti mahdollista jakaa kaikki liikekertoimet kahdella.
} 


\section{Ukko-Pekan joiun analyysi}

A. O. Väisänen (1990, 149-152) analysoi artikkelissaan Ukko-Pekan joiku sodankyläläisen Priita Johanna Maggan (o.s. Ponku) vuonna 1936 joikaamaa joikua, jonka kohteena on tuolloinen Suomen presidentti Pehr Evind Svinhufvud, kansanomaisesti Ukko-Pekka (Esim. 1a). Tarkastelen sekä Väisäsen nuotintamaa joikua että hänen analyysiaan edellä esittelemilläni käsitteillä. Kiinnitän huomion sävelkorkeuksiin ja sävelfunktioihin.

Esimerkki 1a. Väisäsen nuotinnos Ukko-Pekan joiusta (Väisänen 1990, 150).
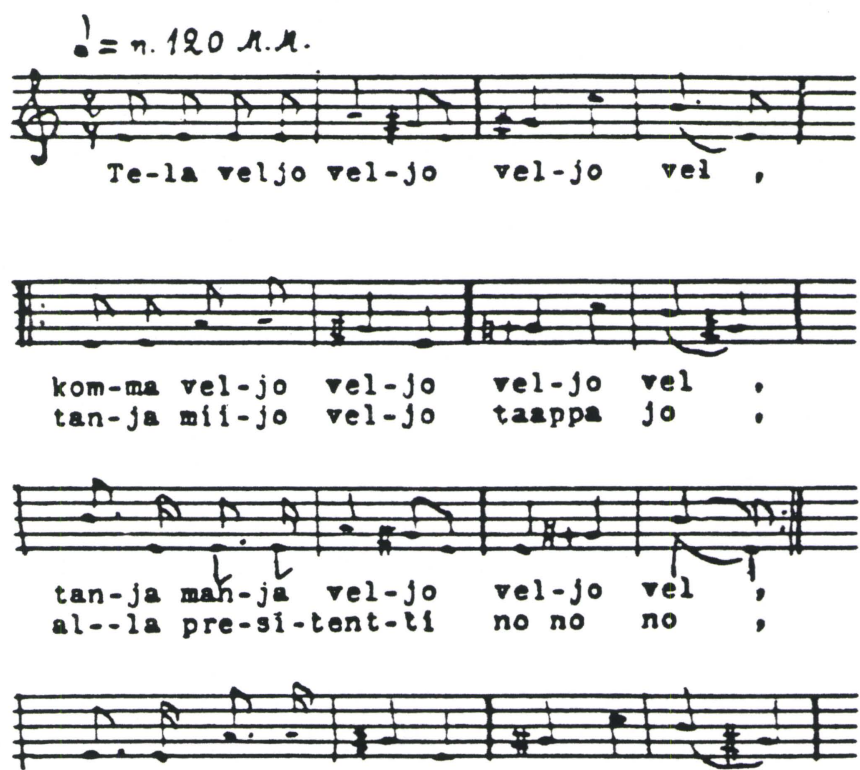

Ad-dja Pek-ka Vil-ju non-no no,
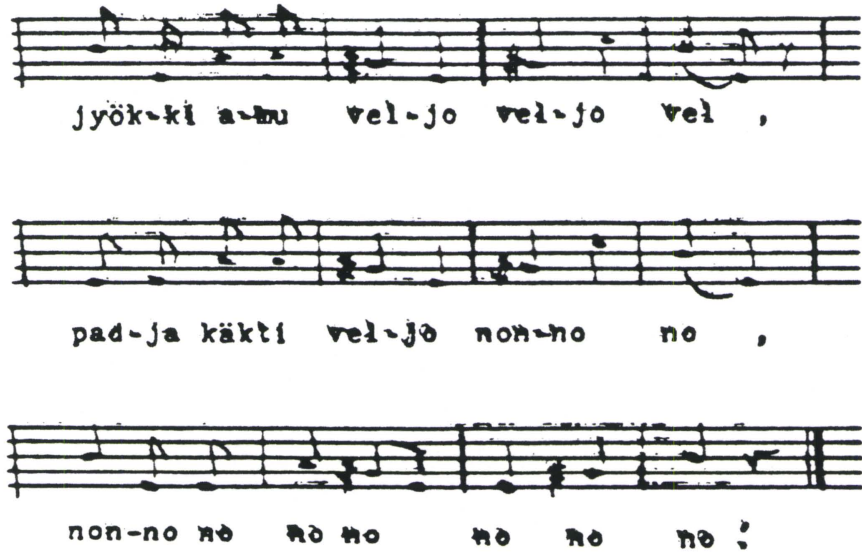
Väisänen on määritellyt sävelikön $\mathrm{e}^{1}-\mathrm{g} \#^{1}-\mathrm{a}^{1}-\mathrm{h}^{1}-\mathrm{c}^{2}$ perussäveleksi $\mathrm{a}^{1}$ :n mitä ilmeisemmin g\#1 $^{1}$ - ja $a^{1}$-sävelien välisen johtosävelsuhteen takia (ks. Esim. 1b). Melodia liikkuu dominantin alisen oktaavin (alakvartin) ja terssin välillä. Väisäsen tulkinta joiun säveljärjestelmästä on plagaalinen mollisävellaji (a-molli) ja siihen liittyvistä sävelsuhteista hän toteaa seuraavaa:

\begin{abstract}
"Kuten rytmillisesti on melodisestikin ensimmäinen tahti muita eloisampi; toteamme siinä muuntelut (merkiten iskulliset sävelet n:oilla): $\mathrm{V}-\mathrm{V}, \mathrm{V}-1,2-\mathrm{V}, \mathrm{V}-1,2-1, \mathrm{~V}-1,2-1$. Milloin ensi tahti päättyy dominttiin (V), alkaa toinen toonikalla eli perussävelellä (1), milloin se taasen nousee toonikalle, on toisen tahdin ensi sävelenä koroitettu johtosävel, jolla varsinkin sävelmän jälkisäkeessä on tärkeä asema. Tältä säveleltä nim. useimmissa kertauksissa tapahtuu jälkisäkeessä hyppäys kiertosävelenä esiintyvälle terssille, ja viimeisen tahdin ensimmäisenä sävelenä on sävykäs teräsävel (dominantinkvintti), josta melodia painuu joko välittäjäilmeiselle johtosävelelle tahi lähtökohtaansa dominantille. Tavallisimmat liikkeet jälkisäkeessä ovat, kun merkitsemme jokaisen neljäsosanuotin: \#VII-3 (vähennetty kvartti), 2-V tai 2-\#VII; toinen, kolmisointukulkuinen liikuntamuoto on: V-\#VII, 2-V.” (Väisänen 1990, 151.)
\end{abstract}

Esimerkki 1b. Väisäsen määrittämä sävelikkö Ukko-Pekan joiusta (Väisänen 1990, 151).

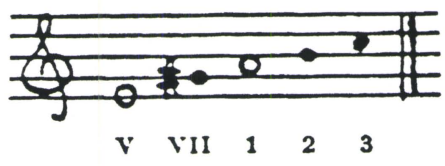

Melodian liikkeiden luonteen kuvauksessa Väisänen käyttää myös ajalleen tyypillisiä kuvauksellisia ilmaisuja kuten:

"...sävelmän kaipaukselliseen yleisilmeeseen yhdistyy melodinen liikesuunta alhaalta ylöspäin (V-2) ikään kuin katse nousisi korkeutta kohti: jotkut alaspäiset kvinttihypyt ilmentävät päättäväisyyttä ja sävelmän lopussa esiintyvä teräsävel odotusta." (Väisänen 1990, 151.)

Vaikka tällaiset ilmaisut tuovatkin musiikin sanalliseen kuvaukseen väriä ja ovat sinänsä lukijalle piristäviä huomioita, on kyseenalaista, antaako joiulle oikeutta vieraasta kulttuurista tulevan tutkijan arviot joikaajan tuntemista tunteista kun hän on joikuaan esittänyt.

Säerakenne. Ongelmana Väisäsen sinänsä loogisessa analyysissa on kuitenkin se, että sävelikössä esiintyvät sävelten väliset tonaaliset jännitteet eivät toteudu itse melodiassa. Johtosävelsuhdetta ei esiinny sen paremmin g\#\# ${ }^{1}: \mathrm{ja}{ }^{1}: n$ välillä kuin $\mathrm{h}^{1}: \mathrm{n}$ ja c²:n välilläkään. Sen sijaan kyseiset sävelet ovat suhteessa toisiinsa vain alaspäisissä melodialiikkeissä. Väisänen siis joutuu käsittelemään joiun melodiaa pieninä paloina saadakseen esiin säveliköstä johtamiaan tonaalisia funktioita.

Joiun kohteen, Ukko-Pekan motiivi on A-säe $\left(\mathrm{e}^{1}-\mathrm{a}^{1}-\mathrm{g} \# \#^{1}-\mathrm{e}^{1}\right)$, jonka ensimmäisenä ja viimeisenä sävelenä on e. Sävelten välisiä suhteita vertailtaessa B-säkeen $\left(\mathrm{g}^{1}-\mathrm{c}^{2}-\mathrm{h}^{1}-\right.$ $\mathrm{e}^{1}$ ) melodinen idea muistuttaa läheisesti $\mathrm{A}$-säettä. Se vain esitetään korkeammalta. 
Ensimmäinen intervalli on hyppy ylös, joka on A-säkeessä pu4 $\left(e^{1}-a^{1}\right)$ ja B-säkeessä $\mathrm{s} 3\left(\mathrm{~g} \#^{1}-\mathrm{c}^{2}\right)$. Toisena intervallina on kummassakin säkeessä alaspäinen puolisävelaskel, p2 $\left(\mathrm{a}^{1}-\mathrm{g} \#^{1}, \mathrm{c}^{2}-\mathrm{h}^{1}\right)$. Kolmantena intervallina on hyppy alas, A-säkeessä s3 $\left(\mathrm{g} \#^{1}-\mathrm{e}^{1}\right) \mathrm{ja}$ B-säkeessä pu5 ( $\left.\mathrm{h}^{1}-\mathrm{e}^{1}\right)$. Hypyt ovat hieman laajempia B-säkeessä kuin A-säkeessä. Bsäkeessä siis hypätään korkeammalle.

Variointi. Eri sävelkorkeuksien paikka suhteessa tekstiin vaihtelee. Säkeitä on esityksessä yhteensä 14 kappaletta, joista 11 on metrin ja melodian kaarroksen kannalta vastaavia. Kolmessa A-säkeessä intervalliliike on tiivistynyt säkeen loppuun. Toinen melodiaa varioiva piirre on se, että säkeen aloittava sävel on jaettu rytmisesti. A-säkeessä $\mathrm{e}^{1}$ :n eteen on lisätty $\mathrm{h}^{1}$. B-säkeessä puolestaan on g\#1-sävelen eteen lisätty $\mathrm{e}^{1}$. B-säkeessä sävel g\#1 on intonoitu kahdesti hieman matalammaksi säveleksi g+. B-säkeessä c ${ }^{2}$ voidaan jättää pois ja käydä pelkästää $\mathrm{h}^{1}$ :llä. Joiun lopettavan B-säkeen viimeinen esävel on myöskin jätetty pois (ks. taulukko 1).

Taulukko 1. Ukko-Pekan joiun melodiset motiivit.

\begin{tabular}{|c|c|c|c|c|c|c|}
\hline & \multicolumn{3}{|c|}{ A-säe } & \multicolumn{3}{|c|}{ B-säe } \\
\hline & & sävelet & intervallit & & sävelet & intervallit \\
\hline 1. & $A$ & $e^{1}-a^{1}-g \#^{1}-e^{1}$ & pu4 $1, \mathrm{p} 2\rfloor, \mathrm{s} 3\rfloor$ & $B$ & $g \#^{1}-c^{2}-h^{1}-e^{1}$ & s31, p2।, pu5」 \\
\hline 2. & A & $e^{1}-a^{1}-g \#^{1}-e^{1}$ & pu4†, p2l, s3! & $\mathrm{B}^{1}$ & $g+{ }^{1}-c^{2}-h^{1}-g \#^{1}$ & $+31, p 2 \downarrow, p 3 \downarrow$ \\
\hline 3. & $A^{1}$ & $h^{1}-e^{1}-a^{1}-g \#^{1}-e^{1}$ & 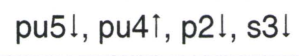 & $\mathrm{B}^{2}$ & $e^{1}-g+1--h^{1}-e^{1}$ & 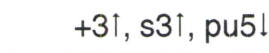 \\
\hline 4. & $A$ & $e^{1}-a^{1}-g \#^{1}-e^{1}$ & pu4 $4, \mathrm{p} 2 \downarrow, \mathrm{s} 3 \downarrow$ & $\mathrm{B}^{1}$ & $g \#^{1}-c^{2}-h^{1}-\#^{1}$ & s31, p2।, p3! \\
\hline 5. & $A^{1}$ & $h^{1}-e^{1}-a^{1}-g \#^{1}-e^{1}$ & pu5l, pu4 4, p 2$\rfloor,$ s3! & $\mathrm{B}$ & $g \#^{1}-c^{2}-h^{1}-e^{1}$ & 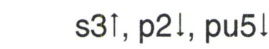 \\
\hline 6. & $A$ & $e^{1}-a^{1}-g \#^{1}-e^{1}$ & pu4†, p2l, s3! & $B$ & $g \#^{1}-c^{2}-h^{1}-e^{1}$ & 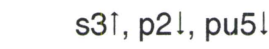 \\
\hline 7. & $A^{1}$ & $h^{1}-e^{1}-a^{1}-g \#^{1}-e^{1}$ & pu5 5 , pu4 4, p 2$\rfloor,$ s3! & $B^{3}$ & $e^{1}-g \#^{1}--h^{1}-$ & s3i, p3† \\
\hline
\end{tabular}

Prominenssiarvot. Melodian kaikkien sävelien eli melodiasävelikön asteista suurimmat prominenssiarvot saa $\mathrm{e}^{\mathbf{1}}(36,95 \%)$ ja g\#1 $(37,54 \%)^{\prime}$. Seuraavaksi suurimman saa $\mathrm{h}^{1}$ $(12,79 \%)$. Muilla sävelillä arvo on alle $10 \%\left(a^{1}=6,20 \%, c^{2}=1,55 \%\right)$, mikä osoittaa niiden vähäisempää merkitystä melodiassa. Keskeisiksi nousevat sävelet $\mathrm{e}^{1}$ - $\mathrm{g \#}^{1}$ - $\mathrm{h}^{1}$, joista muodostuu melodian prominessisävelikkö. Vaikka joiun melodia perustuu ensisijaisesti prominessisävelikön säveliin, voi tilastollisesti marginaalisten sävelten vivahteilla olla suuri merkitys melodiassa ja joikaajan persoonallisessa tyylissä.

Sävelfunktiot. Sävelikön matalin sävel $e^{l}$ on alahyppysävel (AHS), jolta melodia etenee $\mathrm{g}^{1}{ }^{1}$ ja $\mathrm{a}^{1}$-sävelille. Sävelelle tullaan $\mathrm{g \#}^{1}$ - ja $\mathrm{h}^{1}$-säveliltä. Sävel $\mathrm{g}^{I}$ on funktioltaan melodian monipuolisin sävel eli jakajasävel tyyppiä 5 (JS5). Tässä melodiassa sillä on 
yhdistettynä kolme eri perusfunktiota: 1) Se on alavälittäjäsävelenä (AVS) sävelten $\mathrm{a}^{1}$ ja $\mathrm{e}^{1}$ välissä, 2) ylävälittäjäsävelenä (YVS) sävelten $\mathrm{e}^{1} \mathrm{ja}^{1}$ välissä sekä 3) $\mathrm{h}^{1}$-sävelen alahyppysävelenä (AHS) B1 - ja A-säkeiden välissä ( $\left.\mathrm{h}^{1}-\mathrm{g} \#^{1}-\mathrm{h}^{1}\right)$. Sävel $a^{1}$ on ylähyppysävel (YHS). Sävel esiintyy melodiassa vain yhdessä kohdassa, melodian hypätessä e ${ }^{1}$ säveleltä $a^{1}$-sävelen kautta g\#和-sävelelle. Tämä piirre, jossa sävelelle hypätään ylemmän sävelen kautta on hyvin tyypillinen useille joikumelodioille. Sävel $h^{1}$ toimii yhdistetyn funktionsa tapaan kahdella tavalla 1) ylähyppysävelenä (YHS) melodialiikkeessä g\#1_ $\mathrm{h}^{1}$ e $^{1}$ sekä 2) sävelten $\mathrm{c}^{2}$ ja g\# välisenä alavälittäjäsävelenä (AVS). Sävelikön ylin sävel $c^{2}$ on ylähyppysävel (YHS), jolle tullaan g\#1 $^{1}$-säveleltä ja jolta lähdetään $\mathrm{h}^{1}$-sävelelle. Sävelellä on vastaava melodiaa koristava funktio kuin $\mathrm{a}^{1}$-sävelellä ja $\mathrm{c}^{2}$-sävel esiintyy melodiassa vain hypättäessä ylös g\#1 - ja $\mathrm{h}^{\mathbf{1}}$-sävelen välissä.

Joiun melodian sävelfunktiot tukevat prominenssiarvoja. Melodian matalin sävel $\mathrm{e}^{1}$ hahmottuu selvästi joiun keskeisimmäksi säveleksi yhdessä prominenssiarvoltaan vastaavan g\#1-sävelen kanssa. Jälkimmäinen on ainoa sävel, joka on suhteessa kaikkiin muihin melodian säveliin. Näihin kahteen säveleen keskittyy myös eniten melodista liikettä koko melodiassa. Sävel $h^{1}$ kuuluu myös prominenssisävelikköön, mutta sen funktio on vähäisempi. Sävelet $\mathrm{a}^{1}$ ja $\mathrm{c}^{2}$ ovat eräänlaisia yläpuolisia koristesäveliä alapuolisille sävelilleen.

Taulukko 2. Ukko-Pekan joiun melodian sävelikkö, prominenssisävelet ${ }^{15}$ ja sävelfunktiot.

\begin{tabular}{|c|c|c|c|c|c|c|}
\hline Prom. säv.: & $e^{1}$ & g\#1 & $a^{1}$ & $h^{1}$ & $c^{2}$ & Summa \\
\hline Liikekerr.: & 36 & 32 & 14 & 20 & 10 & Säv. \\
\hline kesto: & 28 & 32 & 14 & 20 & 10 & \\
\hline Summa: & 1008 & 1024 & 196 & 400 & 100 & 2728 \\
\hline$\%:$ & $36,95 \%$ & $37,54 \%$ & $7,18 \%$ & $14,66 \%$ & $3,76 \%$ & $100,00 \%$ \\
\hline $\begin{array}{l}\text { Sävelten } \\
\text { väliset }\end{array}$ & $\begin{array}{c}g \#^{1}, a^{1} \searrow \\
e^{1}\end{array}$ & $\begin{array}{c}\lambda^{7 g} \#^{1}, \mathrm{~h}^{1} \\
\mathrm{~g} \# \mathbf{1}\end{array}$ & $\begin{array}{c}a^{1}, h^{1} \searrow \\
a^{1}\end{array}$ & $\begin{array}{c}7 h^{1}, c^{2} \\
\mathbf{h}^{\mathbf{1}}\end{array}$ & $c^{2}$ & \\
\hline suhteet: & & $e^{1 \lambda} \vee e^{1}$ & $e^{1 \lambda} \quad \searrow g \#^{1}$ & $\mathrm{~g} \mathbb{1}^{1} \lambda \quad \vee g \#^{1}, \mathrm{e}^{1}$ & $\mathrm{~g} \# 1 \lambda \quad \mathrm{h}^{1}$ & \\
\hline Sävelfunktio: & AHS & JS5 & YHS & JS4 & YHS & \\
\hline
\end{tabular}

Väisäsen tulkinta Ukko-Pekan joiun tonaliteetista ei saa tukea melodian sävelten prominenssiarvoista. Väisäsen tulkitsemat $\mathrm{a}^{1}$ ja $\mathrm{c}^{2}$ jäävät liian marginaaliseen asemaan (alle $10 \%)$ ollakseen sävellajin perussävel ja terssi. Hän ei kuitenkaan voinut päätyä tulkitsemaan melodiaa e-pohjaisena analyysin lähtökohtana olevan tonaalisen ajattelun vuoksi.

\footnotetext{
${ }^{15}$ Laskin prominenssit vertailun vuoksi myös pelkästään kahden ensimmäisen säeparin mukaan, sillä Launiksen aineistossa ovat nuotinnettuina vain ensimmäiset säeparit. Arvot olivat seuraavat: $\mathrm{e}^{1}: 40,70 \%$, $\mathrm{g \#}^{1}:$ : 38,76\%, $\mathrm{a}^{\mathbf{1}}: 6,20 \%, \mathrm{~h}^{\mathbf{1}}: 12,79 \% \mathrm{ja} \mathrm{c}^{2}: 1,55 \%$. Tulokset siis vastasivat toisiaan.
} 
Pääasiallinen este on g\#-sävelen sävelkorkeuden huojuvuus B-säkeessä. Säveltä ei voi tulkita sävelikön 3. asteen säveleksi, koska silloin ei syntyisi duuri- eikä mollisävellajin vaikutelmaa. Tonaalisen ja pentatonisen sävelikköanalyysin ongelma tiivistyykin siihen, että säveltasot käsitetään divisiivisen sävelikkömallin mukaisesti absoluuttisiksi ${ }^{16}$.

\section{Lukkar Annin joiun analyysi}

Yksittäisten melodioiden sävelsuhteiden analyysin ohella esittelemääni metodia voi soveltaa myös toisintojen melodisen yhteneväisyyden selvittämiseen. Seuraavissa esimerkeissä 2a ja $2 \mathrm{~b}$ on kaksi toisintoa Lukkar Annin joiusta, joista ensimmäisen joikasi Kaapin Jouni (Launis 561a) ja toisen Menesjärven Matti (Launis 561b).

Esimerkki 2a. Launis 561a.
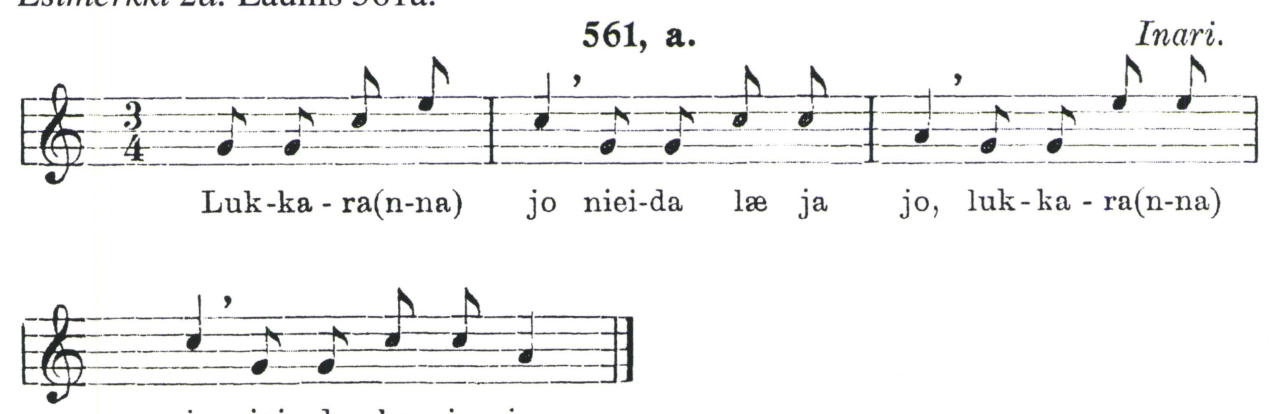

jo niei-da læ ja jo.

Esimerkki 2b. Launis 561b.

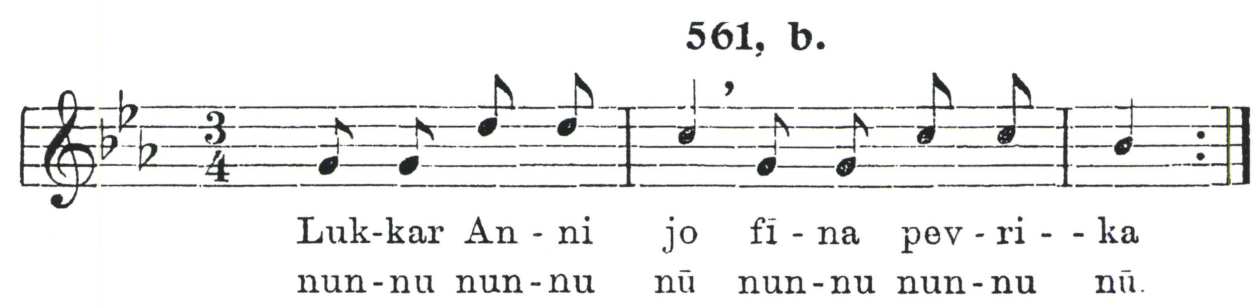

Toisintojen säveliköt eivät hahmotu intervallisuhteiltaan samanlaisiksi. A-toisinnon sävelikkö on $g^{I}-a^{I}-c^{2}-e^{2}$ (S2-P3-S3) ja B- toisinnon sävelikkö on $g^{I}-b^{I}-c^{2}-d^{2}$ (P3S2-S2). Melodioiden vertailussa sukulaisuuden huomaa kuitenkin selvästi. A-toisinto on intervallisuhteiltaan hieman laajempi kuin B-toisinto. Sävelten prominenssiarvot kertovat myös toisintojen sävelasteiden vastaavuudesta. A-toisinnon sävelsuhteet ovat: $\mathrm{g}^{1}: 39 \%, \mathrm{a}^{1}: 10 \%, \mathrm{c}^{2}: 43 \%, \mathrm{e}^{2}: 7 \%$ ja B-toisinnon sävelsuhteet ovat: $\mathrm{g}^{1}: 40 \%, \mathrm{~b}^{1}: 10 \%$, $c^{2}: 40 \%, d^{2}: 10 \%$. 
Kummankin toisinnon prominenssisäveliköksi saadaan $\mathrm{g}^{1}-\mathrm{c}^{2}$. Muut sävelet ovat näitä marginaalisemmassa asemassa. Vaikka additionaalisen säveljärjestelmän oletuksen mukaisesti melodiat eivät välttämättä toteuta absoluuttisia sävelkorkeuksia on näissä toisinnoissa intervallisuhde $\mathrm{g}^{1}-\mathrm{c}^{2}$ on pysynyt samana. Se on siis näiden toisintojen olennainen ja pysyvä sävelikkörakenne. Muut sävelet edustavat joikaajien henkilökohtaista tulkintaa, joiun melodisen perusidean muuntelua.

Sävelfunktioanalyysissa saamme a-toisinnon sävelten funktioiksi AHS-AVS-JS5YHS ja b-toisinnon funktioiksi AHS-AVS-JS4-YHS. Funktiot kertovat, että kummassakin toisinnossa esiintyvät samat melodiset liikkeet. Ainoa poikkeus on se, ettei melodia etene B-toisinnossa 3. asteelta 4. asteelle.

Pentatonisessa analyysissa toisintojen sävelikköjä voidaan vertailla asettamalla P3intervalli samalle kohdalle. Säveliköt voidaan tulkita sol-pentatonisuuden (g-a-c-d-e) vajaamuodoiksi. Tuolloin A-toisinnosta puuttuisi 4. aste $\left(\mathrm{d}^{2}\right)$ ja b-toisinnosta 1. aste $\left(\mathrm{g}^{1}\right)$.

$\begin{array}{ccccccccc}561 \mathrm{a}: \mathrm{g}^{1} & - & \mathrm{a}^{1} & - & \mathrm{c}^{2} & - & \left(\mathrm{d}^{2}\right) & - & \mathrm{e}^{2} \\ & (\mathrm{~S} 2 & - & \mathrm{P} 3 & - & (\mathrm{S} 2) & - & \mathrm{S} 2) & \\ 561 \mathrm{~b}:\left(\mathrm{g}^{1}\right)- & \mathrm{a}^{1} & - & \mathrm{c}^{2} & - & \mathrm{d}^{2} & - & \mathrm{e}^{2} \\ & ((\mathrm{~S} 2) & - & \mathrm{P} 3 & - & \mathrm{S} 2 & - & \mathrm{S} 2) & \end{array}$

Jos joikujen melodiat analysoitaisiin erikseen ilman tekstillistä yhteyttä, ei niiden säveliköitä tulkittaisi välttämättä samanlaisiksi, sillä analyysissa ei olisi mitään perusteita määritellä puuttuvia säveliä. Suurin ongelma pentatonisessa analyysissa on kuitenkin se, että kun pentatoninen sävelikkörakenne redusoidaan melodiaan, ei vastaavuutta toisintojen välillä enää välttämättä löydy. Sävelmä saattaa olla missä asemassa tahansa suhteessa sävelikköön. Melodian sävelasteista kyllä saadaan tiivistettyä säveliköitä, mutta sävelikkörakenteet eivät useinkaan tunnu sopivan siihen käsitykseen minkä saa melodian liikettä tarkkailtaessa tai melodiaa tapaillessa. ${ }^{17}$

Melodioiden tyypittely sävelikköjen perusteella ei kerro mitään siitä, kuinka melodiat toimivat. Kiinnostavaa tutkimuksessa on selvittää itse musiikkia eli melodioiden keskinäisiä sukulaisuuksia, ei vain säveliköiden sukulaisuuksia. Prominenssisäveliköitä vertailtaessa tilanne on toinen, sillä siinä melodioiden hierarkkinen järjestelmä kopioituu myös sävelikköihin.

Launiksen nuotinnosta tarkasteltaessa törmäämme samaan ongelmaan kuin Väisäsen Ukko-Pekan joiun analyyissa. Launis on analysoinut a-toisinnon C-duuriksi ja btoisinnon c-molliksi. Duuria ja mollia ei voida käsittää samaksi duuri-molli-tonaalisessa analyysissa. Jos taas pidämme kiinni pentatonisten sävelrakenteiden hierarkiattomuudesta on edellä esitelty analyysi teoreettisesti mahdoton.

\footnotetext{
${ }^{17}$ Kenties sävelhierarkiattomuuden ajatus on tämän ongelman seurausta.
} 
Suomalaisen joikututkimuksen voi siis jakaa duuri-molli-tonaalisen ja pentatonisen analyysin paradigmoihin. Nämä analyysimallit ovat kuitenkin perustuneet pitkälti muun kuin joiun analysointiin kehiteltyihin metodeihin. Edellä esitetyllä en väitä, etteikö joiussa voi olla piirteitä duuri-molli-tonaalisuudesta tai pentatonisuudesta. Päinvastoin duuri- ja mollisävelmät ovat varmasti vaikuttaneet joikumelodiikkaan viimeistään kirkoissa veisattujen virsien ja saamelaisten alueelle muuttaneiden uudisasukkaiden musiikin kautta. Tätä ei kuitenkaan voida tutkia, jos ei ensin määritellä joikujen omaa säveljärjestelmää, jotain mihin tonaalisuuden vaikutusta voidaan verrata.

Pentatonisen analyysin avulla on koetettu vastata tähän haasteeseen ja etsitty saamelaisten omaa säveljärjestelmää. Pentatoniikka on kuitenkin analyysimallina liian laaja, sillä sitä on käytetty yleisesti kaikenlaisen ei-länsimaisen musiikin analyysiin pohtimatta juurikaan sitä kuinka hyvin pentatoniikka todella kuvaa tutkittavia musiikkeja ${ }^{18}$. Ennemminkin pentatoniikka kuten myös kirkkosävellajit tai moodit ovat usein olleet eräänlaisia tutkijoiden musiikillisia yleiskäsitteitä ja niillä on kuvattu ensisijaisesti sävelikköjä. Näin pentatoninen analyysi on myös usein deduktiivista kuten duuri-molli-tonaalinen analyysikin. Lisäksi pentatoniikka on länsimaisen tutkimuksen käsitteenä syntynyt universaalisen duuri-molli-tonaliteetin evolutionistisena osana, vaikka sitä onkin myöhemmin käytetty ilman kehitysopillista näkökulmaa.

Kummallakaan menetelmällä ei kuitenkaan ole voitu täydellisesti selittää joikujen säveljärjestelmää. Tällainen järjestelmä on kuitenkin olemassa, koska joikaajat tietävät mitä tekevät. Jotta joikujen säveljärjestelmä näkyisi analyysissa ja sille tehtäisiin oikeutta, on ensin lähdettävä yksin joiusta nousevista piirteistä. Vasta sitten joikujen säveljärjestelmää voidaan verrata muihin säveljärjestelmiin ja etsiä sukulaisuussuhteita muihin musiikkeihin.

\section{Lähteet}

\section{Haastattelut}

Ulla Pirttijärven luento Tampereen kansanperinteen laitoksella 2.2.1998. Kirjoittajan hallussa. Juhani Maggan haastattelu Inarissa 20.6. 2001. Kirjoittajan hallussa. Juhani Maggan haastattelu Inarissa 10.8. 2001. Kirjoittajan hallussa.

\section{Kirjallisuus}

Aikio, Samuli \& Kecskeméti, István \& Kiss, Zoltán 1972. Lappische Joiku-Lieder aus Karasjok gesungen von Anders Ivar Guttorm. Helsinki: Suomalais-ugrilainen seura.

Brăiloiu, Constantin 1984. Problems of Ethnomusicology. Käänn. A. L. Lloyd. Cambridge: Cambridge University Press.

\footnotetext{
${ }^{18}$ Esimerkiksi Brăiloiu (1984, 240-241) toteaa pentatoniikan olevan universaali ilmiö.
} 
Hood, Mantle 1982. The Ethnomusicologist. Ohio: The Kent State University Press.

Huttunen, Matti 1993. Modernin musiikinhistoriankirjoituksen synty Suomessa. Acta Musicologica Fennica 18. Helsinki: Suomen musiikkitieteellinen seura.

Jouste, Marko 1998. Change and Metrics in Guhtura-Niilla's yoik. Etnomusikologian vuosikirja 10, toim. Jukka Louhivuori. Helsinki: Suomen etnomusikologinen seura. Ss. 44-64.

Jouste, Marko 2000. Melodinen variointi porosaamelaisen Kaapin-Jounin joiussa. Etnomusikologian vuosikirja 12, toim. Jarkko Niemi. Helsinki: Suomen etnomusikologinen seura. Ss. 44-63.

Järvinen, Minna Riikka 1999. Maailma äänessä. Tutkimus pohjoissaamelaisesta joikuperinteestä. SKS:n toimituksia 762. Helsinki: SKS.

Kádár, György 1990. Saamelaisten joiut unkarilaisten silmin. Lapin Sivistysseuran julkaisuja 48. Helsinki: Lapin Sivistysseura.

Kantola, Tuula, 1984. Talvadaksen joikuperinne. Etnomusikologinen perustutkimus tenonsaamelaisten musiikista. Folkloristiikan tutkimuksia 2. Turku: Turun yliopisto.

Krohn, Ilmari 1916. Musiikin teorian oppijakso I-II: Rytmioppi - säveloppi. Porvoo: WSOY.

Lagercrantz, Eliel 1957-1966. Lappische Volksdichtung I-VII. Suomalais-ugrilaisen seuran toimituksia $112 ; 115 ; 117 ; 120 ; 124 ; 126 ; 141$. Helsinki: Suomalais-ugrilainen seura.

Laitinen, Heikki 1981. Saamelaisten musiikki. Kansanmusiikki, toim. Anneli Asplund \& Matti Hako. SKS:n toimituksia 366. Helsinki: SKS. Ss. 179-198.

Launis, Armas 1908. Lappische Juoigos-Melodien. Helsinki: Suomalais-ugrilaisen seuran toimituksia XXVI. Helsinki: Suomalais-ugrilainen seura.

Leisiö 1978 Saamelaisten vanhakantainen musiikkikulttuuri. Kansanmusiikki 2/78, ss. 2-15.

Leisiö 1988. Kansanmusiikintutkijan perussanastoa. Tampere: Tampereen yliopiston kansanperinteen laitos.

Leisiö, Timo 2001. Läntisen Euraasian laulututkimuksen haasteita ja näköaloja. Musiikin suunta 2001/1, ss. $97-119$.

Lüderwaldt, Andreas 1976. Joiken aus Norwegen. Studien zur Charakteristik und Gesellschaftlichen Bedeutung des Lappischen Gesanges. Bremen: Übersee-Museum Bremen.

Lüderwaldt, Andreas 1980. Samish Music. The New Grove Dictionary of Music and Musicians 16, toim.Stanley Sadie. London: Macmillan Publishers Ltd. Ss. 449-452.

Nettl, Bruno 1956. Music in Primitive Culture. Cambridge: Harvard University Press.

Nettl, Bruno 1964. Theory and Method in Ethnomusicology. New York: The Free Press.

Pekkilä, Erkki 1984. Historiallinen katsaus analyysimetodiikan kehitykseen etnomusikologiassa. $\mathrm{Mu}$ siikki 1984/3-4, ss. 129-187.

Rautio, Riitta 1994. Pitch Relationships in Pentatonic Music. Pentatonism as a Phenomenon. The Finnish Kodály Center Yearbook 1994, toim. Maija Fredrikson \& Anu Sormunen. Jyväskylän yliopiston musiikkitieteen laitoksen julkaisusarja A: tutkielmia ja raportteja 12, Jyväskylä: Jyväskylän yliopisto, ss. 7-23.

Saastamoinen, Ilpo 1994. Rytmikaava-ajattelu saamelaismusiikin hahmotusmallina. Näkökulma joiun muotorakenteiden ja leu'dd-improvisaatioidenanalyysiin. Musiikkitieteen pro gradu -tutkielma, Jyväskylän yliopisto (Painamaton.)

Saastamoinen, Ilpo 1998. Laulu - рии - ruтри. Saamelaismusiikin alkulähteillä. Musiikkitieteen lisensiaattityö, Jyväskylän yliopisto. (Painamaton.)

Sachs, Curt 1962. The Wellsprings of Music, toim. Jaap Kunst. New York: Dacapo.

Tirén, Karl 1942. Die Lappische Volksmusik. Acta Lapponica III. Stockholm.

Väisänen, A. O. 1990. Hiljainen haltioituminen. A. O. Väisäsen tutkielmia kansanmusiikista, toim. Erkki Pekkilä. SKS:n toimituksia 527. Helsinki: SKS. 